\title{
Education and social pedagogy: What relationship?
}

\author{
Peter Moss* and Pat Petrie - UCL Institute of Education, UK
}

\begin{abstract}
This article explores possible relationships between education and social pedagogy. It begins by examining in more detail the theory and practice of social pedagogy, and the profession of social pedagogue widely known in Continental Europe but much less so in the Anglophone world. It then explores some different meanings of education, before considering in more detail the concept of Bildung and its potential for interconnecting education and social pedagogy. It is argued that the relationship between social pedagogy and education depends on the meaning attached to education; and the article ends by considering some implications - for schools, other settings for children and young people, and for their workforces - of choosing a close relationship between education and social pedagogy.
\end{abstract}

Keywords: building, education, social pedagogy, social pedagogue

\section{Introduction}

This article is an opportunity for the authors to address issues of identity and affiliation by reflecting on what seems to us a major theoretical and practical question: what is or might be the relationship between education and social pedagogy? The question is particularly acute since we have worked for many years at an Institute of Education, in London (today named the UCL Institute of Education (IOE)), yet have also studied and advocated for social pedagogy, which we shall argue is a theory and practice that may be seen as potentially closely connected with education. Yet up to now it has been the case that never the twain shall meet. Few in our employing institution, which professes education to be its main purpose, recognize or have an understanding of social pedagogy. The same is true of many similar academic institutions in the UK, and sometimes beyond. At the same time, social pedagogy, at least in the UK, has engaged little with the main field of interest of such educational institutions, schoolbased education.

With our feet in both worlds, this disconnect can seem like a wasted opportunity to develop a productive relationship between education and social pedagogy, which could open up important possibilities for both - for theory and practice, policy and profession. As we shall show, to start enquiring into the relationship leads inevitably to profound questions, critical and political, about the meaning of education and the identity of the educator. We shall argue that the relationship can be distant or very close, depending on the meaning given to education; while from the other direction, it is difficult, if not impossible (or so it seems to us), to think or talk about social pedagogy without referring to education and its meaning. In this process of enquiry, the German concept of Bildung emerges as important, potentially providing common ground for 
both education and social pedagogy. Exploring the relationship also provokes thinking about the place of the school in education and the potential role of social pedagogy in the school; it generates new images of the school and the educator.

In this article, we examine in more detail the history, meanings and enactment of social pedagogy, including the profession of social pedagogue. We then explore some different meanings of education, before considering the concept of Bildung and its potential to interconnect education and social pedagogy. We will end by proposing some implications - for schools, other settings for children and young people, and for their workforces - of choosing to identify a close relationship between education and social pedagogy. Our contention is that a wider and deeper understanding of social pedagogy can enable education, or more specifically school-based education, to be reclaimed from what we see as its current dominant narrow, technical and highly instrumental incarnation, to acquire instead a broader, more holistic understanding, in which the school plays an important role but as only one locus for education.

Our discussion and conclusions draw on 20 years of enquiry into social pedagogy conducted at the UCL IOE, in which we have been involved with other colleagues. We begin, therefore, by reviewing this work, and that of others in the UK, which has contributed to a growing, though belated, knowledge, understanding and practice of social pedagogy in this country.

\section{Social pedagogy}

Social pedagogy is a discipline and practice that is today widespread in Continental Europe, providing the basis for work in a variety of services for children and young people, as well in some cases for adults, work that is undertaken by the profession of social pedagogue. Social pedagogy has a long history, emerging out of Enlightenment thinking as well as from reactions to dire social conditions brought about by the industrial revolution. It was first named as such in 1844 by Karl Mager, a German educationalist, to describe the 'theory of all the personal, social and moral education in a given society, including the description of what has happened in practice' (cited in Winkler 1988: 41; translation by Gabriel, 2000: 1).

Yet despite this long history, social pedagogy until quite recently has been little known in the English-speaking world, its meaning often lost in translation. The term 'pedagogy' is understood in English as the science of teaching and learning, concerned with educational practices in classrooms or schools. An English speaker may assume, therefore, that social pedagogy refers to this didactic science or may be offered, unhelpfully, a translation such as 'education'; while Socialpädagoge and Socialpädagogin, the German terms (masculine and feminine) for social pedagogues, may also be translated inappropriately as 'teachers'. Similar linguistic confusions may arise from, for example, the French terms that describe a similar field and occupation, l'éducation spécialisée and l'éducateur, both of which demonstrate, etymologically, their educational identity, but use 'education' in its broadest sense. Comparable terms are used in other Latinate languages, while Germanic languages have words closer to the German. In this article, social pedagogy and social pedagogue are used throughout.

Despite such linguistic difficulties and past lack of understanding, there is today a growing awareness in the UK of social pedagogy and what it stands for. This has its origins in the last decades of the twentieth century, when a few academics in the UK saw the benefits of a social pedagogic approach for social work (for example, Davies Jones, 1994; Social Education Trust, 2001), but with little focused research, an exception 
being that of Crimmens (1998), who compared training for childcare workers in the Netherlands, Ireland and the UK. The authors had both worked since the early 1970s in fields including early childhood education and care and school-age childcare without coming across social pedagogy. This was to change when, in 1987, one of us set up with European colleagues the European Network for School-age Childcare, and discovered that social pedagogues were employed in German after-school services and that they had much in common with professionals working in similar services in other continental European countries, often known simply as 'pedagogues' or 'free-time pedagogues' (Meijvogel and Petrie, 1996); we were to find through later research that they shared, broadly speaking, a strength-based, collaborative, egalitarian approach and that all had degree-level qualifications (discussed later). One of us then proposed research to the Department of Health, which included reference to pedagogy.

The sustained interest that followed has found expression in various types of work. First, social pedagogy has been the subject of, or a substantial part of, a series of research projects, in particular into the potential or actual role of social pedagogy in services for children in residential and foster care and in family support services, as well as enquiry into the nature of social pedagogy and the education required for professionals in the field. For example, the Department of Health, and later the Department for Education, funded a research and, latterly, a development programme, conducted at the Thomas Coram Research Unit (TCRU) at UCL IOE between 1999 and 2011 (for example, Petrie et al., 2006; Petrie, 2007; Statham, 2013). Other UK funders who have supported development, feasibility and evaluation projects based in or partnered by TCRU include the Department for Children, Schools and Families, KPMG, Esmée Fairbairn Foundation, Comic Relief and the Arts Council England (for example, Cameron et al., 2007; Cameron et al., 2011, Petrie and Knight, 2011, McDermid et al.,2016).

Claire Cameron (2016) overviews ten independent evaluations of residential services for children in care in the UK that had implemented social pedagogy, and found that staff reported less conflict, less running away, more school engagement, more fun and more expression of emotional warmth. Staff facilitated more practical and creative activities for children and were less risk averse. They also referred to theory more, showed improved teamwork and critical reflection, and had greater confidence in communicating with children and colleagues.

Many of the above studies have had a strong comparative element, for example comparing the experience and sometimes the outcomes for children in care in England in so-called 'social care' settings with their peers in countries such as Denmark, the Netherlands, Sweden, Belgium, France and Germany, who were living in social pedagogic settings. A PhD student, supervised by the authors, conducted an important study into differences in social pedagogy in Denmark, Germany and France (Kornbeck, 2014). A European Community-funded project, Care Work in Europe (Cameron and Moss, 2007), explored social pedagogy in different national contexts.

This research has contributed to a growing body of English-language literature on social pedagogy, which, apart from research papers, has also included textbooks (for example, Hatton, 2013; Stephens, 2013; Storo, 2013); edited volumes (for example, Cameron and Moss, 2011; Kornbeck and Rosendal, 2009, 2011, 2012); and the initiation of an online journal, the International Journal of Social Pedagogy (published by UCL Press). Connections with researchers in continental Europe have been created through research and publications and via the Centre for the Understanding of Social Pedagogy. The Centre was established in 2009 at UCL IOE, as a network for academics from 
continental Europe, the UK and further afield, as well as being a home for research and development.

Such work has contributed to a growing and widening interest in social pedagogy in the UK, especially in England and Scotland (for example, Smith, 2009), and not only among academics, but also policymakers and practitioners. This has manifested itself in different ways. A variety of degree courses and modules, at bachelor's and master's level, have been established (at the University of Central Lancaster, the University of Salford, Robert Gordon University and Kingston University, for example); and vocational qualifications at levels three and five have been accredited and delivered. There has been a commitment to working with social pedagogy by a number of local authority children's services departments and non-governmental organizations, and the approach has been endorsed by the Association of Directors of Children's Services (2013). Some hundreds of social pedagogues, qualified in Europe and officially recognized in the UK, have been appointed as social workers or actually as social pedagogues. There is a Social Pedagogy Development Network, which describes itself as 'a place for practitioners, students, service managers and academics alike to find out how organisations up and down the UK (and beyond) have so far developed social pedagogy within their services, and to share ideas and connect with other professionals' (http://www.thempra.org.uk/spdn/); and a Social Pedagogy Professional Association, which was founded in 2017 as 'the professional home for social pedagogy in the UK' (http://sppa-uk.org/).

Having provided this background, we turn now to consider in more detail the meanings applied to social pedagogy and what social pedagogues do.

\section{Social pedagogy: 'Education' and the 'social'}

One way of looking at social pedagogy is from a policy perspective. As Hämäläinen (2003: 71) puts it: 'From the very beginning, the social pedagogical perspective was based on attempts to find educational solutions to social problems'. He also discusses the development of social pedagogy and notes that it has had a more general focus on the promotion of welfare, community life, and the social development of the individual and of the population (Hämäläinen, 2012).

Social pedagogy is about education (pedagogy) in its broadest sense and its relation to the social world. In referring to the social, it goes beyond justifiable concerns about, for example, an individual person's social exclusion, because it is interested in both immediate relationships and in their wider social context. It takes account of how social, political and cultural factors underlie policies and provisions and explores how these underpin the educational processes involved in human formation and the professional and other relationships associated with it. Paul Natorp (1899/1974: 98, cited in Sünker and Braches-Chyrek, 2009: 16), an influential nineteenth-century philosopher and social pedagogic thinker, wrote:

The term social pedagogy therefore means ... that just as individual education is socially conditioned in every possible direction ... on the other hand, a human organization of social life is fundamentally conditioned by the appropriate education of the individuals who want to participate in it.

Natorp focused on the individual as belonging to a human community (Gemeinschaft), proposing:

a social pedagogy, which aims to encourage a strong sense of community, educates both children and adults to ensure positive relations between 
the individual and society, and fights to close the gap between rich and poor. All of these aims are significant for societal well-being and people's sense of responsibility for each other. (Eichsteller and Holtoff, 2011: 40)

A distortion of social pedagogy, divorced from the notions of community, human respect and equality espoused by Natorp, may be seen in the pedagogic youth work and schooling of the German Third Reich. Here, the importance of the state replaced that of the community. Under this regime, social pedagogy was deployed to produce social conformity and to further fascistic ends, through the, ultimately, oppressive collective experience of those young people deemed 'worthy of education', and the extermination of those judged as 'ineducable' or 'incorrigible' (Sünker and BrachesChyrek, 2009: 1). Such pedagogy was fundamentally instrumental in that it treated people as the object of the state, subject to its educational aims, and not as active partners in their own formation and in the formation of their communities.

By contrast, the social pedagogy we have researched or observed in many continental European countries (for example, Petrie et al., 2006), and subsequent experience in development work with social pedagogues recruited from continental Europe, reveal generally democratic values (for example, McDermid et al., 2016). A third variant is what is known as critical social pedagogy, which has a strong emancipatory and activist element, both theoretically and in practice. As Hans Thiersch (cited in Schugurensky, 2014: 9) says of this orientation:

The role of the social pedagogue is to help people to critically analyze their problems, reflecting on the social causes of individual problems and to find options for a successful everyday life. The focus is connecting help for the individual with political action in the context of social justice and well-being, while recognizing social and political resources.

This critical orientation in social pedagogy is infused with Kant's Enlightenment goal of releasing people from self-incurred tutelage, their inability to make use of understanding without direction from another. There is a commitment, therefore, to ending submission to authority, the achievement of consciousness and sustaining the process of self-formation; creating the subject as a protagonist, a self-determining actor, 'an entity that builds or creates itself and in a way that is not pre-ordained' (Moss, 2013: 29). Again, this commitment to ending subjugation embraces the social as well as the individual:

When the social pedagogue is represented as a 'reflective practitioner' ..., this not only refers to reflecting on one's pedagogical action as such, but also on the meaning of one's action with regard to societal relations .... Lorenz ... argues that the social in social pedagogy is not unambiguous. It could lead either to a hegemonous, controlling view on education, shared by all institutions, or it could be seen as the 'critical conscience of pedagogy'. (Coussée et al., 2010: 796)

\section{Social pedagogy: Qualifications and practice}

Social pedagogues are graduate professionals, who have usually undertaken vocational degrees of three to four years, or a longer master's degree, both supplemented by continuing professional education. Lower-level courses can lead to employment but not to qualification; in many countries, unqualified social pedagogues are in the minority in, for example, children's residential care. Degree courses draw on appropriate theories 
such as learning, attachment, group dynamics and systems theories. There are also specifically social pedagogic theories such as 'the common third', which refers to one way in which social pedagogues build relationships: the sharing, on an equal footing, of activities with the people they work with - whether everyday (such as washing up), one-off visits or creative experiences. Modules on the arts, outdoor pursuits or sports furnish the students with skills and understandings to bring to their work (see, for example, Petrie et al., 2006; Petrie and Chambers, 2010), There is also a strong emphasis on practice placements.

Their theoretical and practical education qualifies social pedagogues for work in a wide range of educational and welfare services across the life course (Kornbeck and Rosendal Jensen, 2011, 2012). While the school is not precluded for some social pedagogic roles, currently social pedagogues mostly work in services with the potential to promote informal learning, rather than in those with a formal curriculum. As well as a diversity of services, social pedagogues work with many different groups: children and young people, families, community outreach and other work with adults.

Whatever type of setting they work in and with whatever type of group, social pedagogues attach great importance to creativity and creative activities. Such activities, for example, can provide opportunities for shared experiences that can constitute the common third. They are also an important means of engaging the feelings and the senses, of enhancing self-esteem and a sense of achievement, of opening up to some of the good things in life, and of generating a sense of wider possibilities and identity (Petrie, 2014).

Often working in group settings, associative life, teamwork and co-operation are highly valued by social pedagogues. They see themselves and others they work with as inhabiting the same 'life space', rather than occupying some separate hierarchical domain. They value the particular resources that a group offers, the richness of experience and perspectives, and opportunities for mutual support as well as their own professional contribution. This would hold good in, for example, a senior citizens' lunch club, a staff meeting, a residential setting or a family support meeting.

A distinctive feature of social pedagogy's educational identity is a holistic approach that is both practical and theoretical. Since its inception,

what has most distinguished and differentiated social pedagogy from other pedagogies has been its tendency to understand the person as a whole. In social pedagogy body, mind, emotions, and spirit are integrated in each person's relationship with the rest of the living world. (Úcar, 2012: 132)

Regarding children, social pedagogy is an approach:

in which learning, care, health, general wellbeing and development are viewed as totally inseparable, a holistic idea summed up in the pedagogical term 'upbringing'. The pedagogue as practitioner sees herself as a person in relationship with the child as a whole person, supporting the child's overall development. (Boddy et al., 2005: 3)

Given social pedagogy's holistic perspective, social pedagogues bring themselves - head, heart and hands - to this work, and with personal as well as professional experience to offer. As professionals, they are aware of their responsibilities towards others, bringing professional knowledge, skills and attitudes to their tasks and intentions. At the same time, they see themselves as fellow human beings with other people, with personal feelings, hopes, fears and humour that they are not afraid to 
share. But they also judge which matters are private and should remain so, deciding what is for sharing and what would be inappropriate.

Social pedagogues are reflective practitioners, encouraged constantly to examine their practice and to apply both theoretical knowledge and self-knowledge to the sometimes challenging demands that confront them. Rather than following predetermined procedures, to be applied irrespective of context or circumstance, they seek to understand, using theoretical, practical and self-knowledge, why something has happened and how best to respond to it. They take account of particular circumstances before forming a judgement or making a decision, aware that there are few universal answers: everything depends on the particular circumstances involved.

In this brief description of the practice of social pedagogy, we have outlined both its social and its pedagogic aspects. We have emphasized how an important part of its identity is as an educational approach to social problems. Social pedagogy offers informal education based in non-hierarchical relationships. It often takes place in the course of everyday activities, recognizing their potential for informal learning and for supporting the developing agency and self-realization of those concerned. We see it as education in its broadest sense. We turn now to look at this and other possible meanings of 'education', as typically used in the English-speaking world.

\section{Education and Bildung}

Within the English-speaking world, with its distant or non-existent relationship with social pedagogy, education has various meanings. Most are closely attached to explicitly educational institutions, be they schools, colleges or universities, all places intended for formal learning. These meanings might be seen as situated on a continuum. At one end is education in its narrowest sense, which 'equates education with schooling and certain kinds of formal learning focused wholly or mainly on cognitive capacities and, often, compartmentalised subjects. ENS [education in its narrowest sense] is closer to the way in which education is often understood and publicly debated today' (Fielding and Moss, 2011: 47). This is an education of transmission, predetermined standards, testing and examinations, with schools at risk of being reduced to what has been called 'exam factories' (Coffield and Williamson, 2011). It is an education, too, that emphasizes the individual and competition, prefiguring a world dominated by an increasingly competitive and unforgiving market economy.

At the other end of the spectrum comes what might be termed education in its broadest sense,

a long-established concept of education that understands education as fostering and supporting the general well-being and development of children and young people, and their ability to interact effectively with their environment and to live a good life. This is education as a process of upbringing and increasing participation in the wider society, with the goal that both individual and society flourish. (Moss and Haydon, 2008)

This meaning given to education has found sustained expression in the progressive education tradition, a product of the late nineteenth century that came to hold sway, according to which country is under consideration, during the 40 years between 1930 and 1970, though its roots go back much further to writers such as Comenius and Rousseau. It remains a significant, though marginalized, presence today. This tradition, it has been argued (Darling and Nordenbo, 2003), has five recurring themes, which 
show strong correspondence with the defining features of what we have termed education in its broadest sense:

- Criticism of traditional education: in particular, models that rest primarily on the transmission of information, usually in an authoritarian instructional manner, with no significant place for the active involvement of the student in her own learning.

- The nature of knowledge: emphasizing the importance of young people's previous experience, how they make sense of that experience, the kinds of things that intrigue them or interest them, and the sorts of things they wish to explore.

- Human nature: viewing the child as naturally curious with an inveterate desire for learning.

- Democracy: insisting on the close link between schooling and democracy, understood not so much as a set of procedural arrangements, but rather as a way of learning and living together. Here the emphasis is not just on the child as a learner, but also the child as an agent in their own and each other's lives. The school is thus seen as a major site, not only of curricular engagement, but also of communal and, ultimately, deliberative, democratic living.

- Education of the whole person.

Another perspective on the idea of a holistic or broad education, which recognizes that education may take place in many settings and the central role of relationships, is contained in Walter Feinberg's $(2016: 26,27,34)$ contention that

all education, deserving of the name, whether conducted in private, religious, or public schools, through the family or church, whether formal or informal, share [sic] a singular aim - the construction and development of a self ... conscious self-development ... a relational process in which the identity of the self is formed through interaction and where engagement with the other is critical in a constitutive but not determinant way.

This in turn leads to another discourse about education, and one which is turned to in pedagogy generally and in social pedagogy: the German concept of Bildung. Bildung emerges in eighteenth-century Germany, influenced initially by Protestant pietism and with earlier medieval roots, before becoming secularized. The original meaning of Bildung is:

difficult to translate, but in essence it refers to the inner development of the individual, a process of fulfilment through education and knowledge ... a secular search for perfection ... an interior process by which the individual could work on the self ... the development of the individual as a cultural-ethical personality. (Watson, 2010: 53)

Like the English term 'education', Bildung too has acquired a variety of meanings, often being used today in a narrow and highly instrumental form, referring to the reproduction of stable and pre-determined knowledge through transmission. But the original German concept of Bildung retains a presence, conveying the conception that the potential of a human being is as an entity that builds or creates herself or himself and in a way that is not pre-ordained, a process of self-development or self-formation:

Bildung is consequently something that humans do for themselves, an active business that entails an educator of ability who increases the individual's possibility of freedom ... One of the Enlightenment project's basic ideas was faith in humans' reasoning ability to free humans socially, politically and culturally. This emancipatory way of thinking came from the 
idea that all humans have the possibility to actively create knowledge and the courage to think for themselves. (Dahlberg and Lenz Taguchi, cited in Moss, 2013: 29)

But this concept of Bildung is not an exercise in individualism, for 'Bildung's most important subject is people as a whole and not, as one can be led to believe, the individual himself' (ibid.), its concern being with how people participate in society. Moreover, the exercise of Bildung is a relational practice, involving relationships with others:

The acquiring of knowledge must be understood as a process that assumes an active interaction with other people and phenomena in the environment ... The dialogical principle - the dialogical way of thinking - is involved in a long philosophical tradition with its origins in PlatoSocratic dialogues ... During the 1900s Martin Buber developed and clearly formulated in his main work, I and Thou [Ich und Du], the idea that individual existence can only be developed in the presence of other people in similar circumstances ... Knowledge is, for Buber, not something that individual people have or possess, but something one establishes or brings about through relationships to the world. (ibid.)

Speaking about a 1994 report she co-authored for a Swedish government commission on the relationship between pre-school and school, one of the authors, Gunilla Dahlberg, discusses the different meanings of Bildung. She acknowledges that the time it 'was often interpreted as an elitist project as well as a narrow education ... often interpreted as an individualistic project' (Dahlberg, 2013: 84). However, she and the coauthor of the report, Hillevi Lenz-Taguchi, drew on the very different original German conception of Bildung: the human being is, or should be, a being that constructs her/ himself into something not decided beforehand. Viewed from this perspective, Bildung is an active undertaking, which implies an increase in the individual's possibilities for freedom, drawing on Kant's desire that we have courage to use our own reason without direction from someone else.

Dahlberg and Lenz-Taguchi, in their report, connected this Enlightenment view of Bildung to the 'progressive traditions of education expressed by educators like John Dewey and Elsa Köhler, with their emancipatory ambitions and their image of the human being as a participatory citizen constructing meaning and knowledge' (ibid.). Understood in this 'classical German' way, as an emancipatory pedagogical philosophy connecting the whole of society, Bildung clearly has much in common with the concept of education in its broadest sense and with the theory of social pedagogy.

\section{Social pedagogy and education: Distant or close relations}

It seems to us that it is difficult, if not impossible, to think of a way of conceptualizing and talking about social pedagogy that does not refer to education - for social pedagogy is an educational theory and practice. But the term 'social' has an equally prominent place in its name, which opens the way for a critical appraisal of the place of schools and educational policies as these relate to the individual person, to society's subgroups, and to other social institutions and systems. In this article, however, we focus mainly on the educational and pedagogical. 
We can certainly find a way of conceptualizing and talking about the provision and practice of education that is not social pedagogic - indeed much contemporary educational discourse in the Anglophone world today, with its narrow, technical and instrumental perspective, has little or nothing to do with social pedagogy. However, if we take a broad view of education, if we work with the concept of education in its broadest sense or with the classic concept of Bildung, then education and social pedagogy do appear to have much in common; indeed they overlap to a large extent. Perhaps the main difference is that the term 'education', even used in its broadest sense, often has a close association with the school (or other such formal learning settings), whilst social pedagogy always views education as happening in many places and many forms, informal as well as formal.

Social pedagogy, therefore, might be seen as an overarching concept capable of spanning and infusing many areas of public policy, all areas in fact that involve working with children, young people and adults in informal or formal settings. As such, it means the application of an educational perspective and educational means to social issues - but educational understood in a particular way, as we have set out above: a process of change, the development of agency, modification, 'becoming' and transformation. These settings naturally include the school, which might share a social pedagogic orientation along with other services for children and young people. For from a theoretical perspective, the school can be viewed as a social pedagogic provision because it sets out to address social issues by educational means (although in an era of education in its narrowest sense, today's schools do not usually comply with current understandings of good social pedagogy practice as outlined previously).

Sharing this particular educational orientation, seeing and identifying schools as social pedagogic provision would have profound implications for their identity and functioning. They would be viewed as important, though not the only, environments for pursuing education in its broadest sense, distinct from other such environments by virtue of their universality, their formality and their structure. They might, however, accommodate other social pedagogic provisions (operating as an 'extended school') or form close relations with such provisions housed elsewhere, relationships fostered by a shared educative orientation of social pedagogy. Schools so conceptualized would therefore have a clearly social purpose and adopt an explicitly holistic approach, in which creativity would have a large role to play. All those working within such schools might have had a professional education that included social pedagogic theories and practices, though there might still be different professions represented, including teachers and social pedagogues working in teams; such a model operates in the Swedish 'whole day' school, where mixed age groups of children are organized into units (arbetslag), each unit having a multi-professional team of educators including pre-school teachers, school teachers and 'free-time' pedagogues (Cohen et al., 2004; Johansson and Moss, 2012).

We started this article by expressing a sense of disconnect, indeed a feeling of confusion, arising from working with social pedagogy in an Institute of Education, when the relationship between social pedagogy and education is undefined, indeed unacknowledged. We have subsequently attempted to explore that relationship, asking the question 'what relationship?' and answering it in a typically social pedagogic way: it depends. It depends, in particular, on what we mean by education. Given certain meanings, the relationship is very distant. But given other meanings, the relationship between social pedagogy and education can be very close, both, too, being closely related to the original meaning of Bildung. Of course, an Institute of Education could make it clear that the meaning of education was an open question, a contestable 
subject; and that social pedagogy constituted one possibility, an educational concept and approach with a strong pedigree that an Institute of Education recognized and valued, taught and researched, not least because it provided a conceptual framework for locating the school in a strong and equal partnership with other educational environments, rather than treating it as an autonomous, isolated and dominant institution.

\section{Notes on the contributors}

Peter Moss is Emeritus Professor at UCL IOE, University College London. His interests focus on early childhood education and care, democracy in education and the relationship between care, employment and gender. His books include Radical Education and the Common School (with Michael Fielding), Transformative Change and Real Utopias in Early Childhood Education and Parental Leave and Beyond (edited with Ann-Zofie Duvander and Alison Koslowski).

Pat Petrie is Emeritus Professor at the UCL IOE, University College London, in the Centre for Understanding Social Pedagogy (CUSP). Her early professional experience, before turning to research, was as a teacher. She has researched social pedagogy in continental Europe and supported its development in the UK. Her studies include policy and practice towards looked-after children, family support, the extended school, day nurseries, childminders, play and school-age childcare.

\section{References}

ADCS (Association of Directors of Children's Services) (2013) ADCS Position Statement: What is care for? Alternative models of care for adolescents. Manchester: Association of Directors of Children's Services. Online. https://tinyurl.com/y2f4queu (accessed 24 July 2019).

Boddy, J., Cameron, C., Moss, P., Mooney, A., Petrie, P. and Statham, J. (2005) Introducing Pedagogy into the Children's Workforce: Children's Workforce Strategy: A response to the consultation document. London: Thomas Coram Research Unit.

Cameron, C. (2016) 'Social pedagogy in the UK today: Findings from evaluations of training and development initiatives'. Pedagogía Social: Revista Interuniversitaria, 27, 199-223.

Cameron, C., McQuail, S. and Petrie, P. (2007) Implementing the social pedagogic approach for workforce training and education in England: a preliminary study. Online. www.ioe.ac.uk/study/departments/tcru/4804.html (accessed 1 October 2019).

Cameron, C. and Moss, P. (2007) Care Work in Europe: Current understandings and future directions. London: Routledge.

Cameron, C. and Moss, P. (eds) (2011) Social Pedagogy and Working with Children and Young People: Where care and education meet. London: Jessica Kingsley Publishers.

Cameron, C., Petrie, P., Wigfall, V., Kleipoedszus, S. and Jasper, A. (2011) Final Report of the Social Pedagogy Pilot Programme: Development and implementation. London: Thomas Coram Research Unit. Online. https://core.ac.uk/download/pdf/156876049.pdf (accessed 24 July 2019).

Coffield, F. and Williamson, B. (2011) From Exam Factories to Communities of Discovery: The democratic route. London: Institute of Education.

Cohen, B., Moss, P., Petrie, P. and Wallace, J. (2004) A New Deal for Children? Re-forming education and care in England, Scotland and Sweden. Bristol: Policy Press.

Coussée, F., Bradt, L., Roose, R. and Bouverne-De Bie, M. (2010) 'The emerging social pedagogical paradigm in UK child and youth care: Deus ex machina or walking the beaten path?'. British Journal of Social Work, 40 (3), 789-805.

Crimmens, D. (1998) 'Training for residential child care workers in Europe: Comparing approaches in the Netherlands, Ireland and the United Kingdom'. Social Work Education, 17 (3), 309-20.

Dahlberg, G. (2013) 'A dialogue with the co-author of "the vision of a meeting place"'. In Moss, P. (ed.) Early Childhood and Compulsory Education: Reconceptualsing the relationship. London: Routledge, 72-90. 
Darling, J. and Nordenbo, S.E. (2003) 'Progressivism'. In Blake, N., Smeyers, P., Smith, R. and Standish, P. (eds) The Blackwell Guide to the Philosophy of Education. Oxford: Blackwell, 288-308.

Davies Jones, H. (1994) 'The social pedagogues in Western Europe - some implications for European interprofessional care'. Journal of Interprofessional Care, 8 (1), $19-29$.

Eichsteller, G. and Holthoff, S. (2011) 'Conceptual foundations of social pedagogy: A transnational perspective from Germany'. In Cameron, C. and Moss, P. (eds) Social Pedagogy and Working with Children and Young People: Where care and education meet. London: Jessica Kingsley Publishers, 33-52.

Feinberg, W. (2016) What is a Public Education and Why We Need It: A philosophical inquiry into self-development, cultural commitment, and public engagement. Lanham, MD: Lexington Books.

Fielding, M. and Moss, P. (2011) Radical Education and the Common School: A democratic alternative. London: Routledge.

Gabriel, T. (2000) Social Pedagogy and Residential Care in Germany. Unpublished report for the Thomas Coram Research Unit, Institute of Education, University of London.

Hämäläinen, J. (2003) 'The concept of social pedagogy in the field of social work'. Journal of Social Work, 3 (1), 69-80.

Hämäläinen, J. (2012) 'Social pedagogical eyes in the midst of diverse understandings, conceptualisations and activities'. International Journal of Social Pedagogy, 1 (1), 3-16.

Hatton, K. (2013) Social Pedagogy in the UK: Theory and practice. Lyme Regis: Russell House Publishing.

Johansson, I. and Moss, P. (2012) 'Re-forming the school: Taking Swedish lessons'. Children and Society, 26 (1), 25-36.

Kornbeck, J. (2014) 'Convergence and Divergence in Conceptualising the Professions of Social Work and Social Pedagogy and Their Professional Education, and the Question of Europeanisation: Germany, Denmark and Belgium (1989-2004)'. Unpublished PhD thesis, Institute of Education, University of London.

Kornbeck, J. and Rosendal Jensen, N. (eds) (2009) The Diversity of Social Pedagogy in Europe. Bremen: Europäischer Hochschulverlag.

Kornbeck, J. and Rosendal Jensen, N. (eds) (2011) Social Pedagogy for the Entire Lifespan: Volume 1. Bremen: Europäischer Hochschulverlag.

Kornbeck, J. and Rosendal Jensen, N. (eds) (2012) Social Pedagogy for the Entire Lifespan: Volume 2. Bremen: Europäischer Hochschulverlag.

McDermid, S., Holmes, L., Ghate, D., Trivedi, H., Blackmore, J. and Baker, C. (2016) The evaluation of Head, Heart, Hands: Introducing social pedagogy into UK foster care. Final synthesis report, executive summary. Online. https://tinyurl.com/y6mrt25q (accessed 1 October 2019).

Meijvogel, R. and Petrie, P. (1996) School-Age Childcare in the European Union: A survey. London: European Commission Network on Childcare and Other Measures to Reconcile Employment and Family Responsibilities of Men and Women.

Moss, P. (2013) 'The relationship between early childhood and compulsory education: A properly political question'. In Moss, P. (ed.) Early Childhood and Compulsory Education: Reconceptualising the relationship. London: Routledge, 2-49.

Moss, P. and Haydon, G. (eds) (2008) Every Child Matters and the Concept of Education (Viewpoint 17). London: Institute of Education.

Natorp, P. (1899) Sozialpädagogik: Theorie der Willenserziehung auf der Grundlage der Gemeinschaft. Stuttgart: Frommann.

Natorp, P. (1974) Sozialpädagogik. Paderborn: Schöningh.

Petrie, P. (2007) 'Foster care: A role for social pedagogy?'. Adoption and Fostering, 31 (1), 73-80.

Petrie, P. (2014) 'Social justice and social pedagogy'. In Cooper, C., Gormally, S. and Hughes, G. (eds) Socially-Just Radical Alternatives for Education and Youth Work Practice. Re-Imagining Ways of Working with Young People. Basingstoke: Palgrave MacMillan, 85-106.

Petrie, P., Boddy, J., Cameron, C., Wigfall, V. and Simon, A. (2006) Working with Children in Care: European perspectives. Maidenhead: Open University Press.

Petrie, P. and Chambers, H. (2010) Richer Lives: Creative activities in the education and practice of Danish pedagogues: Report to Arts Council England. Online. www.sppa-uk.org/wp-content/uploads/2017/09/social-pedagogy-and-the-arts-v3.pdf (accessed 25 July 2019). 
Petrie, P. and Knight, A. (2011) I Want to Sing. Sing Up/NCB Looked After Children Programme Evaluation. Online. http://www.singup.org/fileadmin/singupfiles/previous_uploads/Sing_Up_ Looked_After_Children_full_report.pdf (accessed 1 October 2019)

Schugurensky, D. (2014) 'Social pedagogy and critical theory: A conversation with Hans Thiersch'. International Journal of Social Pedagogy, 3 (1), 4-14.

Smith, M. (2009) 'Social work as social education: The possibilities of social pedagogy in Scotland', European Journal of Social Education, 16/17, 229-39.

Social Education Trust (2001) 'Social Pedagogy and Social Education (formerly known as the Radisson Report): A report of two workshops held on 11th-12th July 2000 and 14th-15th January 2001 at the Radisson Hotel, Manchester Airport'. Online. https://tinyurl.com/y3d4c42j (accessed 25 July 2019).

Statham, J. (2013) Supporting Young People on the Edge of Entering Public Care: Cross national perspectives (Research Briefing 4). London: Institute of Education. Online. http://discovery.ucl.ac.uk/10018578/ (accessed 25 July 2019).

Stephens, P. (2013) Social Pedagogy: Heart and head. Bremen: Europäischer Hochschulverlag.

Storø, J. (2013) Practical Social Pedagogy: Theories, values and tools for working with children and young people. Bristol: Policy Press.

Sünker, H. and Braches-Chyrek, R. (2009) 'Social pedagogy in Germany'. In Kornbeck, J. and Rosendal Jensen, N. (eds) The Diversity of Social Pedagogy in Europe. Bremen: Europäischer Hochschulverlag, 12-33.

Úcar, X. (2012) 'Social pedagogy in Latin America and Europe: Looking for new answers to old questions'. In Kornbeck, J. and Rosendal Jensen, N. (eds) Social Pedagogy for the Entire Lifespan: Volume 2. Bremen: Europäischer Hochschulverlag, 166-200.

Watson, P. (2010) The German Genius: Europe's third renaissance, the second scientific revolution and the twentieth century. London: Simon and Schuster.

Winkler, M. (1988) Eine Theorie de Sozialpädagogik. Stuttgart: Klett-Cotta. 